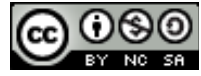

https://doi.org/10.31743/abmk.13186

PIOTR ZAKRZEWSKI* - LUBLIN

\title{
UTWÓR I NOŚNIK UTWORU FOTOGRAFICZNEGO W DZIAŁALNOŚCI MUZEÓW I ARCHIWÓW KOŚCIELNYCH
}

\section{Streszczenie}

Kategorie fotografii znajdujących się w muzeach i archiwach kościelnych są zróżnicowane. Różnorodność ta w połączeniu z faktem, że fotografia oddaje za pomocą środków technicznych obraz rzeczywistości, budzi pytania, czy i jakie fotografie są utworami podlegającymi ochronie prawno-autorskiej. Przeważa pogląd, że fotografia odzwierciedla obraz rzeczywistości, ale w sposób zmieniony przez fotografa, co tym samym pozwala potencjalnie zakwalifikować ją do kategorii utworu. W polskim piśmiennictwie i orzecznictwie na przestrzeni lat zmieniało się postrzeganie wymagań, którym musi ona odpowiadać, aby mogła zostać uznana za utwór. Początkowo za takie uważano jedynie fotografie, odznaczające się artyzmem (pięknem) osiągniętym dzięki staraniom fotografa, np. estetyczne ustawienie osób, operowanie światłem. Pogląd taki wydaje się być ciągle prezentowany w piśmiennictwie niemieckim. Stopniowo rozpoczął się proces bardziej liberalnego postrzegania spełniania przez fotografie wymagań stawianych utworom. Kluczowe znaczenie przyznano subiektywnemu obrazowi rzeczywistości - utrwalonemu przez twórcę - który każdorazowo odróżnia się od kolejnego takiego obrazu nawet tej samej rzeczywistości. Jeżeli subiektywny obraz, oparty na wyborze fotografa, uchwyconego fragmentu rzeczywistości rozstrzyga o spełnieniu wymagań stawianych utworom, to każda fotografia jest utworem z wyjątkiem tych, które pozbawione są elementu wyboru, np. zdjęcia legitymacyjne. Dominującemu stanowisku należy jednak zarzucić zbyt liberalne rozumienie przesłanek warunkujących powstanie utworu. W muzeach i archiwach znajdują się odbitki fotograficzne, które nie mogą być utożsamiane z utworem fotograficznym. Nośnik utworu fotograficznego oraz utwór fotograficzny są innymi kategoriami pojęciowymi

\footnotetext{
* Piotr Zakrzewski - dr hab. nauk prawnych, prof. KUL, Instytut Nauk Prawnych, Katolicki Uniwersytet Lubelski Jana Pawła II

e-mail: piotr.zakrzewski@kul.pl

https://orcid.org/0000-0003-4981-1480
} 
i prawnymi, w szczególności pierwszy z nich jest rzeczą, wobec której przysługuje prawo własności, a drugi - przedmiotem prawa autorskiego. Posiadanie praw do nośnika nie daje prawa korzystania z autorskich praw majątkowych.

Słowa kluczowe: archiwa kościelne, muzea, prawo autorskie, utwór fotograficzny, zbiory

$* * * * *$

Fotografie znajdujące się w muzeach ${ }^{1}$ i archiwach $^{2}$ kościelnych, a dokumentujące m.in. funkcjonowanie Kościołów, zakonów i innych instytucji kościelnych oraz życie osób duchownych, zakonnych i świeckich, zaliczają się do odmiennych kategorii fotografii, np. wykonywanych powszechnie przy różnych okazjach, reporterskich, artystycznych czy przedstawiających dzieła sztuki i architektury sakralnej. Stanowi to przyczynę trudności w ocenie, czy konkretna fotografia jest utworem $^{3}$. Rozstrzygnięcie tego jest istotne, ponieważ w przypadku pozytywnej odpowiedzi do utworu fotograficznego znajduje zastosowanie ustawa z dnia 4 lutego 1994 r. o prawie autorskim i prawach pokrewnych ${ }^{4}$. Utwór fotograficzny staje się z mocy prawa przedmiotem autorskich praw osobistych i majątkowych, które przysługują twórcy i podlegają ochronie. Obrót zaś autorskimi prawami majątkowymi następuje na podstawie wspomnianej ustawy. Zagadnienia te, uwzględniając w szczególności digitalizację utworu fotograficznego, mają kompleksową regulację prawną. Ponieważ fotografia oddaje rzeczywistość uchwyconą przez fotografa, powstaje pytanie, pod jakimi warunkami staje się ona utworem fotograficznym. Celem artykułu jest przedstawienie odpowiedzi na to pytanie oraz wynikających z nich konsekwencji, istotnych w działalności muzeów i archiwów.

Trudność, która występuje w kwalifikacji fotografii jako utworu, wynika ze specyfiki tego rodzaju dzieł. W przypadku dzieł innego rodzaju stają się one przedmiotami ochrony ze względu na formę, którą uzyskały w zamiarze autora. Tymczasem fotografia w dużym stopniu oddaje za pomocą środków technicznych istniejącą rzeczywistość ${ }^{5}$. Fotografia stanowi więc uchwycony w pewnej chwili zapis obrazu fragmentu rzeczywistości, z którym jednak odbiorca obcuje za pośrednictwem twórczej wyobraźni fotografa. Fotograf konstruuje w umyśle pewną wizję, którą chce przenieść na obraz, a następnie zamierzenie to realizuje, dobierając odpowiednie środki wyrazu i modyfikując obraz rzeczywistości. To w przekształceniu przez fotografa i wyrażaniu w obrazie obserwowanej rzeczywistości, upatrywać należy działalności twórczej i indywidualnej, przesądzającej

${ }^{1}$ Ustawa z dnia 21 listopada 1996 r. o muzeach (tekst jedn.: Dz. U. z 2020 r. poz. 902).

${ }^{2}$ Ustawa z dnia 14 lipca 1983 r. o narodowym zasobie archiwalnym i archiwach (tekst jedn.: Dz. U. z 2020 r. poz. 164 z późn. zm.)

${ }^{3}$ Zob. J. Barta, R. Markiewicz, Przedmiot prawa autorskiego, w: System prawa prywatnego. Prawo autorskie, t. 13, red. J. Barta, Warszawa 2007, s. 30.

${ }^{4}$ Tekst jedn.: Dz. U. z 2021 r. poz. 1062.

${ }^{5}$ U. Loewenheim, Das Werk, w: Urheberrecht. Kommentar, Hrsg. G. Schricker, München, 1999; cyt. za R. M. Sarbiński, Utwór fotograficzny i jego twórca w prawie autorskim, Kraków 2004, s. 353. 
o zaistnieniu utworu fotograficznego. Stopień i zakres przekształcenia obrazu rzeczywistości przez fotografa w praktyce jest bardzo różny w zależności od rodzaju fotografii, np. artystycznej czy powstałej w wyniku tzw. pstrykania. To z kolei wywołuje sygnalizowaną powyżej trudność w ocenie, czy konkretna fotografia jest utworem.

Jak wynika z powyższego, uznanie fotografii za utwór stanowi interpretacyjne wyzwanie. Kwestia ta była przedmiotem ożywionej dyskusji podczas tworzenia ustawy z dnia 29 marca 1926 r. o prawie autorskim ${ }^{6}$. Ostatecznie przeważył pogląd dopuszczający uznanie fotografii za utwór, o ile - według art. 1 tejże ustawy - spełniała ona przesłanki utworu, tj. stanowi przejaw działalności duchowej odznaczającej się osobistą twórczością ${ }^{7}$ Podobnie czyni obowiązująca ustawa o prawie autorskim ${ }^{8}$ (dalej: u.p.a.), stanowiąc, że przedmiotem prawa autorskiego są utwory fotograficzne (art. 1 ust. 2 pkt. 3 u.p.a). Utwór fotograficzny - jak każde inne dzieło - musi być przejawem działalności twórczej o indywidualnym charakterze (art. 1 ust. 1 u.p.a.). Pod pojęciem działalności twórczej człowieka rozumie się taką działalności, jaka - choć w minimalnym stopniu - odróżnia się od innych rezultatów. Innymi słowy, działalność twórcza ma dać wynik cechujący się nowością, obecną w utworze w choćby w niewielkim stopniu?. Pojęcie działalności twórczej wyjaśnia się także od strony negatywnej: jako przeciwieństwo banalności, oczywistości, naśladownictwa ${ }^{10}$. Poza tym utwór musi mieć indywidualny charakter, czyli powinien się odznaczać swoistymi właściwościami nadanymi mu przez osobowość jego twórcy. Dzięki indywidualnemu charakterowi nowy rezultat działalności człowieka jest także niepowtarzalny. Nie ma swojego odpowiednika w przeszłości i istnieje wysoki stopień prawdopodobieństwa, że w przyszłości nie zostanie stworzony przez innego twórcę identyczny utwór ${ }^{11}$. Max Kummer posługiwał się w związku z tym określeniem „unikalność utworu" ${ }^{2}$. Pomimo że w piśmiennictwie niekiedy kwestionuje się celowość rozróżnienia pojęć „twórczy” i ,indywidualny” w definicji utworu, gdyż coś indywidualnego jest jednocześnie twórcze ${ }^{13}$, to krytyka ta nie wydaje się zasadna $\mathrm{z}$ racji pomijania faktu, że unikalność działa wyłącza powstanie podobnego utworu w przyszłości.

${ }^{6}$ Dz. U. z 1926 r. Nr 48, poz. 286.

${ }^{7}$ Sarbiński, Utwór fotograficzny i jego twórca, s. 89.

${ }^{8}$ Ustawa z dnia 4 lutego 1994 r. o prawie autorskim i prawach pokrewnych (tekst jedn.: Dz. U. z 2021 r. poz. 1062).

${ }^{9}$ M. Poźniak-Niedzielska, Przedmiot prawa autorskiego, w: System prawa prywatnego. Prawo autorskie, t. 13, red. J. Barta, Warszawa 2007, s. 8; szerzej zob. J. Błeszczyński, Twórczość jako przesłanka ochrony $w$ polskim prawie autorskim $w$ świetle doktryny i orzecznictwa, w: Współczesne problemy prawa prywatnego. Księga pamiątkowa ku czci profesora Edwarda Gniewka, red. J. Gołaczyński, P. Machnikowski, Warszawa 2010, s. 27-28.

${ }^{10}$ Sarbiński, Utwór fotograficzny i jego twórca, s. 72.

${ }^{11}$ Poźniak-Niedzielska, Przedmiot prawa autorskiego, s. 9.

${ }^{12}$ M. Kummer, Das urheberrechtlich schützbare Werk, Bern 1968; cyt. za M. Poźniak-Niedzielska, Przedmiot prawa autorskiego, s. 9; Błeszczyński, Twórczość jako przesłanka ochrony, s. 30-31.

${ }_{13}$ J. Barta, R. Markiewicz, Glosa do wyroku SA w Gdańsku z dnia 29 stycznia 1993 r. AGCr 369/92, „Orzecznictwo Sądów Polskich”, (1993) nr 11, poz. 216; Sarbiński, Utwór fotograficzny i jego twórca, s. 73. 
Obowiązujące prawo autorskie, chociaż dopuszcza uznanie fotografii za utwór, nie wyjaśnia jednak pojęcia utworu fotograficznego. Jego wyjaśnieniem zajęto się dopiero w orzecznictwie i piśmiennictwie ${ }^{14}$, np. Sąd Najwyższy w uzasadnieniu wyroku z dnia 10 maja $1976 \mathrm{r}^{15}$ stwierdził, że ,utwór fotograficzny stanowi obraz «przedmiotów» uzyskany przy stosowaniu właściwych mu sposobów i środków (utwór plastyczny)". Sąd ten zaznaczył także, że obraz, aby mógł być uznany za utwór, musi spełniać ogólne przesłanki utworu, którymi są twórcza i indywidualna działalność fotografa. Na przestrzeni lat rozumienie twórczego i indywidualnego charakteru fotografii w polskim orzecznictwie i piśmiennictwie ulegało jednak zmianie. Jej kierunek można opisać jako coraz bardziej liberalną ocenę spełniania przez fotografię przymiotów twórczego i indywidualnego charakteru. Początkowo za twórczą uznawano jedynie fotografię będącą utworem artystycznym, czyli odznaczającym się artyzmem rozumianym jako piękno fotografii czy jej wysoki poziom estetyczny ${ }^{16}$. Reprezentatywna jest tu wypowiedź Stefana Rittermana, który uznawał fotografię za utwór, jeżeli „fotografujący włożył własną inwencję w odtworzeniu osób czy przedmiotów fotografowanych". „Inwencja fotografa musiała jednak wchodzić w zakres artyzmu, w zakres sztuki przedstawiania”. „A więc chodzić będzie o umiejętne, estetyczne ustawienie osób, dostarczenie należytego - z punktu widzenia artystycznego - światła, kunsztowne cieniowanie przy retuszu itp." ${ }^{17}$. Z takim stanowiskiem doktryny pozostawało w zgodzie, orzecznictwo Sądu Najwyższego, choć sąd ten nie podjął próby wyjaśnienia, czym jest artystyczny utwór fotograficzny ${ }^{18}$.

Wydaje się, że podobnie postrzega się utwór fotograficzny na gruncie współczesnego prawa niemieckiego. Według Haimko Schacka utwór fotograficzny wyróżnia się przez artystyczną siłę twórczą, przez merytoryczny wyraz ${ }^{19}$. Podobny pogląd wyraża Manfred Rehbinder: za utwór fotograficzny mogą być uznane zdjęcia, w których artystyczna koncepcja i siła twórcza fotografa jest wyrażona przez wybór motywu, obróbkę, światło i cienie, retusz, fotomontaż lub użycie innych artystycznych środków wyrazu, np. niezwykła perspektywa lub kadr ${ }^{20}$. Fotografie nie będące utworami, nie pozostają jednak bez ochrony prawnej. Przepisy o ochronie utworów stosuje się odpowiednio do ochrony fotografii, które utwo-

${ }^{14}$ Zob. Sarbiński, Utwór fotograficzny i jego twórca..., s. 65-64.

${ }^{15}$ IV CR 127/76, „Orzecznictwo Sądu Najwyższego. Izba Cywilna”, 1977, nr 4, poz. 69.

${ }^{16}$ Sarbiński, Utwór fotograficzny i jego twórca..., s. 93; zob. Ł. Pers, Utwory fotograficzne w regulacjach prawa autorskiego od czasów II Rzeczypospolitej do chwili obecnej. Analiza prawnoporównawcza, „Studenckie Zeszyty Naukowe”, 22 (2019), nr 41, s. 130-135.

${ }^{17}$ S. Ritterman, Komentarz do ustawy o prawie autorskim, Kraków 1937, s. 7.

${ }^{18}$ Orzeczenie Sądu Najwyższego z dnia 12 marca 1958 r., II CR 374/57, „Orzecznictwo Sądów Polskich", 1959, z. 5, poz. 125; uzasadnienie wyroku Sądu Najwyższego z dnia 8 sierpnia 1978 r., II CR 242/78, LEX nr 63857.

${ }^{19}$ H. Schack, Urheber- und Urhebervertragsrecht, Tübingen 2005, s. 104.

${ }^{20}$ M. Rehbinder, Urheberrecht, München 2008, s. 82. 
rami nie są (w niemieckiej ustawie o prawie autorskim i pokrewnych prawach chronionych $\S 72)^{21}$.

W piśmiennictwie i orzecznictwie polskim stopniowo zaczęto odchodzić od postrzegania fotografii jako utworu tylko, gdy odznacza się ona pięknem. Wskazywano na brak oparcia dotychczas prezentowanego poglądu w przepisach ${ }^{22}$. Jego zwolennicy wskazywali, że fotografia uwolniła się od swoistego ciężaru, którym było postrzeganie jej przez pryzmat sztuk pięknych i - co się z tym wiąże - skupiania uwagi tylko na jej wartości estetycznej. Podkreślali oni, że fotografia spełnia także inne funkcje, np. poznawcze, informacyjne, historyczne. Ich zdaniem twórczego charakteru fotografii należy upatrywać również $\mathrm{w}$ innych obszarach niż tylko estetyczne ${ }^{23}$.

Zwolennicy liberalnego rozumienia utworu fotograficznego wskazują, że postrzeganie fotografii jako obrazu rzeczywistości nakazuje doszukiwać się przejawu twórczości i indywidualności w subiektywnej wizji rzeczywistości wybranej przez fotografa. Stanowi ona wynik twórczego i indywidualnego wyboru przez twórcę, który decyduje się zawrzeć rzeczywistości w obrazie ${ }^{24}$. Dokonany przez fotografa wybór jest pierwszorzędnym, choć nie jedynym działaniem twórczym. Konsekwencją takiego poglądu jest to, że w przypadku fotografii, w której nie występuje dokonany przez fotografa wybór obrazu rzeczywistości, np. ze względu na przeznaczenie fotografii, nie można także mówić o twórczym działaniu ${ }^{25}$.

Wśród działań fotografa, które mogą być ocenione jako twórcze i indywidualne, a które przesądzają o powstaniu utworu fotograficznego, wymienia się wybory: wycinka fotografowanej rzeczywistości, czasu jej dokonania, kompozycji, czyli wzajemnych relacji między elementami tej rzeczywistości, linii zamykających fotografowany przedmiot (kadr), punktu fotografowania, a w przypadku zdarzeń dynamicznych moment wykonania zdjęcia, jak również wybór perspektywy, jasność, barwę, ostrość, efektów światła, kształtowania obrazu czarnobiałego, kształtowanie obrazu podczas obróbki laboratoryjnej albo w technice cyfrowej, efekty specjalne itp. ${ }^{26}$ Wymienione elementy są obecne w fotografiach artystycznych, ale przyjmuje się, że występują także w powszechnie wykonywanych fotografiach okazyjnych.

${ }^{21}$ Gesetz vom 09.09.1965 über Urheberrecht und verwandte Schutzrechte, BGBl. I S. 1273, zuletzt geändert durch Gesetz vom 31.05.2021, BGB1. I S. 1204 [Ustawa z dnia 9 września 1965 r. o prawie autorskim i pokrewnych prawach chronionych, Federalny Dziennik Ustaw I, s. 1273 ze zm., ostatnia zm. przez ustawę z dnia 31 maja 2021 r., Federalny Dziennik Ustaw I, s. 1204].

${ }^{22}$ A. Karpowicz, Konstrukcje prawne w dziedzinie w dziedzinie ochrony twórczości fotograficznej, „Refleks”, (1971) nr 17-18, s. 74; J. Błeszczyński, Prawo autorskie, wyd. 3, Warszawa 1988, s. 56; zob. B. Michalski, Problemy prawne fotografii artystycznej, „Refleks”, (1970) nr 14, s. 96-97; Sarbiński, Utwór fotograficzny i jego twórca, s. 98.

${ }^{23}$ Sarbiński, Utwór fotograficzny i jego twórca, s. 92-93.

${ }^{24}$ Tamże, s. 113.

${ }^{25}$ Tamże, s. 114.

${ }^{26}$ Tamże, s. 116-117; wyrok Sądu Apelacyjnego w Poznaniu z dnia 30 czerwca 1992 r., I ACr 220/92, „Orzecznictwo Sądów Apelacyjnych”, (1993) nr 4, poz. 24; J. Łukaszczyk, Fotografia jako przedmiot prawa autorskiego - zarys problematyki elementów twórczych w fotografi, „Naukowy Przegląd Dziennikarski”, (2016) nr 3, s. 23-24. 
Pogląd, że dokonany przez fotografa wybór zakresu obrazu rzeczywistości, czasu wykonania, światła itp. skutkuje za każdym razem powstaniem obrazu odznaczającego się twórczym i indywidualnym charakterem, prowadzi do przyjęcia bardzo szerokiego rozumienia fotografii jako utworu. Każda fotografia, w której można się dopatrzeć subiektywnej pracy nad oddaniem obrazu rzeczywistości (np. wyborem jej fragmentu), dokonana przez fotografa jest utworem fotograficznym. Nie ma znaczenia, czy fotografię dokonał zawodowy fotograf, czy amator, czy jej wykonanie wymagało dużego, czy małego nakładu pracy oraz jakie narzędzia zostały użyte do jej wykonania.

Utworami fotograficznymi będą nie tylko jedyne w swoim rodzaju fotografie wybitnych artystów, lecz także fotografie o przeznaczeniu użytkowym, wykonywane przy różnych okazjach. $\mathrm{Z}$ tego zakresu będą wyłączone tylko te fotografie, w których składniki obrazu nie są wynikiem wyboru fotografa, np. fotokopie, reprodukcje obrazów, tkanin lub innych obiektów płaskich, zdjęcia wykonane zgodnie ze ściśle ustalonymi założeniami, np. zdjęcia dokumentacyjne, legitymacyjne ${ }^{27}$.

Za liberalnymi ujęciami warunków uznania fotografii za utwór ${ }^{28}$ podążyło także orzecznictwo Sądu Najwyższego upatrujące twórczości w

świadomym wyborze momentu fotografowania, punktu widzenia, kompozycji obrazu (kadrowania), oświetlenia, ustalenia głębi, ostrości i perspektywy, zastosowania efektów specjalnych oraz zabiegi zmierzające do nadania fotografii określonego charakteru, elementy te bowiem nadają fotografii indywidualne piętno, konieczne dla uznania istnienia utworu w rozumieniu Prawa autorskiego ${ }^{29}$.

Ocena aktualnego stanowiska doktryny i orzecznictwa zakładającego, że utworem fotograficznym jest każdy subiektywny obraz rzeczywistości stanowiący wybór fotografa, ponieważ różni się on od innych podobnych obrazów rzeczywistości wykonanych przez innych fotografów, nie jest prosta. Przywołane stanowisko prowadzi do zapewnienia prawno-autorskiej ochrony niemal każdej fotografii. Dokonuje się to jednak kosztem liberalnej wykładni przesłanek „działalności twórczej o indywidualnym charakterze". Szczególnie ta ostatnia przesłanka rozumiana powszechnie za M. Kummerem jako unikalność utworu, czyli jego statystyczna niepowtarzalność, wydaje się występować w bardzo wąskim zakresie. Wykonane przy różnych okazjach proste zdjęcie, może być w łatwy sposób po-

${ }^{27}$ Sarbiński, Utwór fotograficzny i jego twórca, s. 151-152; J. Barta, R. Markiewicz, Przedmiot prawa autorskiego, w: Prawo autorskie i prawa pokrewne. Komentarz, red. J. Barta,Warszawa 2007, s. 30.

${ }^{28}$ Zob. A. Stelmach, Kopciuszek prawa autorskiego, „Prawo i Życie”, (1967) nr 8, s. 4; T. Grzeszak, Droit de suite w prawie autorskim, Warszawa 1991, s. 78; Barta, Markiewicz, Przedmiot prawa autorskiego, s. 31; K. Grzybczyk, Przedmiot prawa autorskiego [art. 1, nb 96], w: Ustawa o prawie autorskim i prawach pokrewnych. Komentarz, red. P. Ślęzak, Warszawa 2017, s. 5-40. Przeciwne stanowisko zob. R. Golat, Prawo autorskie i prawa pokrewne, Warszawa 1999, s. 26.

${ }^{29}$ Wyrok Sądu Najwyższego z dnia 5 lipca 2002 r., III CKN 1096/00, „Orzecznictwo Sądu Najwyższego. Izba Cywilna”, 2003, nr 11, poz. 150. Por. E. Ferenc-Szydełko, Przedmiot prawa autorskiego, w: Ustawa o prawie autorskim i prawach pokrewnych. Komentarz, red. E. Ferenc-Szydełko, Warszawa 2011, s. 36-37. 
wtórzone, a efekt końcowy będzie odróżniał się od pierwowzoru w niewielkim zakresie. Można zapytać nawet, czy efekt takiej twórczości nie jest oczywisty, banalny, co stanowi zaprzeczenie twórczości z art. 1 ust. 1 u.p.a. Trudno także w takim przypadku operować pojęciem plagiatu utworu fotograficznego, skoro wspomniane utwory są do siebie bardzo zbliżone, a twórczy i indywidualny charakter dzieła jest niewielki. Należy również zastanowić się, czy zapewnienie ochrony prawno-autorskiej niemal każdej fotografii przez 70 lat odpowiada celowi ustawy o prawie autorskim i prawach pokrewnych, a także czy w ten sposób nie dochodzi do deprecjonowania działalności twórczej artystów fotografików. Wprawdzie liberalna wykładnia pojęcia utworu fotograficznego nie pozbawia fotografii artystycznej ochrony, ale dzieła takie są trudno zauważalne wśród licznych utworów fotograficznych odznaczających się minimalnym wkładem twórczym fotografa.

Wprawdzie wykładnia językowa art. 1 ust. 1 u.p.a. nie daje podstaw do przyjęcia, że tylko fotografie odznaczające się artyzmem są utworami, ale powstaje pytanie, czy artyzm nie powinien być traktowany - ze względu na przynależność fotografii do kategorii sztuk wizualnych - jako synonim działalności twórczej oraz indywidualnego charakteru. Wydaje się, że zaletą przyznania ochrony jedynie dziełom fotograficznym odznaczającym się artyzmem jest ochrona tych twórców, którzy wnieśli rzeczywisty wkład twórczy w swoje dzieło. Wyłączenie poza nawias utworów chronionych tych fotografii, które nie są nacechowane artyzmem, wywołuje jednak na gruncie prawa polskiego pytanie o ich status prawny? Wydaje się, że powszechność i znaczenie takich zdjęć we współczesnym społeczeństwie, wymaga objęcia także takich fotografii ochroną, ale mniej intensywną w porównaniu do utworów. De lege ferenda zasadne byłoby rozważenie zapewnienia fotografiom, które nie spełniają wymogów stawianych utworom fotograficznym odznaczającym się artyzmem, takiej ochrony, jaką cieszą się prawa pokrewne (zob. art. 94 n. u.p.a.). Byłoby to przeniesienie na grunt polski rozwiązań niemieckich. Podział na utwory fotograficzne i fotografie chronione, jak prawa pokrewne, wydaje się lepiej odpowiadać celowi prawa autorskiego. Oczywiście rozwiązanie takie wywoła problem dostrzegany w literaturze niemieckiej, a polegający na trudności w ocenie, czy fotografia jest utworem, czy zasługuje jedynie na ochronę jak prawo pokrewne ${ }^{30}$.

W kwestii oceny czy fotografia jest utworem, prawo polskie i niemieckie podążyło innymi ścieżkami. W przypadku pierwszego z nich nastąpiło zliberalizowanie przesłanek $z$ art. 1 ust. 1 u.p.a., w efekcie czego przyznano ochronę autorską niemal wszystkim fotografiom. Wydaje się, że jednym z powodów była tu chęć rozciągnięcia ochrony na te dzieła, co do których zachodziła wątpliwość, czy są utworami, np. zdjęcia reporterskie ze względów społecznych. W przeciwnym razie ich twórcy nie podlegaliby intensywnej ochronie. $\mathrm{W}$ prawie niemieckim nie doszło natomiast do poszerzenia pojęcia utworu fotograficznego, lecz zachowano formalną dystynkcję między nim a fotografią, którą poddano ochronie na innych zasadach. Ostatecznie jednak każdy z tych systemów prawa autorskiego przyznaje fotografii ochronę, ale na zróżnicowanych zasadach.

${ }^{30}$ Schack, Urheber- und Urhebervertragsrecht, s. 104. 
Mając na uwadze aktualnie dominujące stanowisko w kwestii uznawania fotografii za utwór, można przyjąć, że zdecydowana większość fotografii znajdująca się w muzeach i archiwach jest utworami. Może się jednak okazać, że muzea i archiwa często są w posiadaniu jedynie odbitek fotograficznych. Wymaga to zwrócenia uwagi na różnicę między utworem fotograficznym a jego nośnikiem. Każdy utwór, w tym fotograficzny, jest dobrem niematerialnym, czyli oderwanym od swojej materialnej podstawy bytowej, dzięki której istnieje i może być poznawany ${ }^{31}$. Odbiór niematerialnego utworu fotograficznego przez odbiorców jest więc możliwy dzięki jego utrwaleniu na przedmiocie materialnym, tzw. nośniku utworu (corpus mechanicum), takim jak negatyw, diapozytyw lub odbitka fotograficzna, a współcześnie w przypadku fotografii cyfrowej także na nośnikach elektronicznych, np. płycie DVD. Niematerialny utwór fotograficzny nie może być utożsamiany z jego materialnym nośnikiem, np. wspomnianą odbitką fotograficzną. Choć utwór i jego materialny nośnik łączą się niekiedy w sposób niemożliwy do rozdzielenia, stanowią odrębne kategorie pojęciowe i prawne.

Odróżnienie nośnika utworu fotograficznego od utworu fotograficznego będącego dobrem niematerialnym oznacza, m.in. że powstanie, nabycie i obrót prawami majątkowymi do wspomnianych dóbr następuje zgodnie z przepisami prawa. Nabycie nośnika utworu, czyli przedmiotu materialnego (art. 45 Kodeksu cywilnego; dalej: k.c.), następuje na podstawie umów sprzedaży, darowizny itp., które nie wymagają zachowania szczególnej formy pod rygorem nieważności (art. 890 $\S 1$ k.c.). W praktyce funkcjonowania archiwów i muzeów kościelnych do nabycia odbitek fotograficznych często dochodzi w wyniku nieformalnej umowy darowizny. Jeżeli jednak umowa nie była podstawą nabycia odbitek fotograficznych, a muzeum lub archiwum weszło w ich posiadanie w inny sposób niż umowne nabycie od właściciela, to nie stanowi to przeszkody nabycia własności tych rzecz. Może ona nastąpić m.in. w drodze zasiedzenia po upływie trzech lat, jeżeli posiadacz był w dobrej wierze (art. 174 k.c.; zob. też art. 169). Muzea i archiwa są zatem właścicielami odbitek fotograficznych stanowiących ich zbiory.

W inny sposób następuje nabycie autorskich praw majątkowych do utworu. Te bowiem przypadają z mocy prawa twórcy utworu, czyli fotografowi, który wykonał zdjęcie. Zasada ta jest utrzymana także wtedy, gdy wykonując zdjęcie fotograf, wypełniał obowiązki wynikające z umowy o pracę, która obejmowała wykonywanie zdjęcia (art. 12 u.p.a). Wówczas przyjmuje się, że autorskie majątkowe prawa do utworu fotograficznego przechodzą na pracodawcę na mocy postanowień umowy o pracę, która przewiduje takie przejście. Autorskie prawa majątkowe podlegają dziedziczeniu (art. 41 u.p.a.; art. 922 k.c.). Obrót tymi prawami jest sformalizowany, a ich przejęcie przez nabywcę wymaga zachowania formy pod rygorem nieważności (art. 53 u.p.a).

Może więc dochodzić do sytuacji, w której archiwum i muzeum posiada własność nośnika utworu fotograficznego, ale nie posiada praw do utworu. Jeżeli muzeum lub archiwum jest wprawdzie właścicielem nośnika materialnego danego

${ }^{31}$ Zob. A. Kopff, Dzieto i jego twórca, w: Zagadnienia prawa autorskiego, S. Grzybowski, A. Kopff, J. Serda, Warszawa 1973, s. 18. 
utworu fotograficznego, ale nie nabyło autorskich praw majątkowych do utworu, to wykluczone jest wykonywanie autorskich praw majątkowych polegające na utrwalaniu, zwielokrotnianiu, np. tworzeniu kolejnych odbitek zdjęć czy dokonywaniu digitalizacji utworu, oraz rozpowszechnianiu, np. udostępnianiu utworu $\mathrm{w}$ internecie (art. 17 i 50 u.p.a).

Jednak w drodze wyjątku ${ }^{32}$ muzea oraz archiwa mogą w ograniczonym zakresie i jedynie dla osiągania ustawowych celów wykonywać autorskie prawa majątkowe, które im nie przysługują, np. użyczać - w zakresie swoich zadań statutowych - egzemplarze utworów rozpowszechnionych, zwielokrotniać utwory (np. fotograficzne) znajdujące się we własnych zbiorach w celu uzupełnienia, zachowania lub ochrony tych zbiorów oraz udostępniać zbiory dla celów badawczych lub poznawczych za pośrednictwem końcówek systemu informatycznego (terminali) znajdujących się na terenie tych jednostek, jeżeli czynności te nie są dokonywane w celu osiągnięcia bezpośredniej lub pośredniej korzyści majątkowej (art. 28 ust. 1 pkt. 1-3 u.p.a.). Zwielokrotnienie utworów znajdujących się we własnych zbiorach może być wykonywane samodzielnie przez muzea lub archiwa lub zlecane innym podmiotom. Zwielokrotnianie polega na tworzeniu nośników materialnych utworów lub ich cyfrowej postaci, nawet jeżeli pierwotnie nie miały one takiej postaci ${ }^{33}$. Zwielokrotnienie utworów nie może jednak zwiększać liczby egzemplarzy utworów użyczanych lub udostępnianych za pomocą terminali (art. 28 ust. 2 u.p.a.). Zatem zwielokrotnianie utworów znajdujących się we własnych zbiorach w celu ich uzupełnienia, oznacza tylko możliwość wykonania ich kopii cyfrowej. Zmierzając do uzupełnienia zbiorów, muzeum lub archiwum nie może sięgać do zasobów innych muzeów i archiwów ${ }^{34}$. Zwielokrotnianie utworów w celu ich zachowania lub ochrony przeciwdziała utracie spowodowanej, np. pogorszeniem jakości nośnika materialnego ${ }^{35}$.

W przeciwieństwie do autorskich praw osobistych, które nie wygasają i muszą być zawsze respektowane przez użytkowników utworu (art. 16 i 78 u.p.a.), autorskie prawa majątkowe są ograniczone czasowo i gasną po upływie 70 lat $\mathrm{z}$ reguły od śmierci twórcy utworu (art. 36 u.p.a). Konsekwencją ich wygaśnięcia jest to, że po upływie tego terminu każda osoba może - z zastrzeżeniem poszanowania praw osobistych twórcy - swobodnie i nieodpłatnie korzystać z utworu.

${ }^{32}$ Nie wykluczone, że inne przepisy ustawy o prawie autorskim i prawach pokrewnych regulujące przypadki dozwolonego użytku utworów chronionych pozwolą muzeom i archiwom na używanie utworu chronionego bez zezwolenia uprawnionego. W tym kontekście można przywołać art. 25 ust. 1 pkt. 1c u.p.a., który pozwala na rozpowszechnianie w celach informacyjnych w prasie, radio i telewizji aktualnych fotografii fotoreporterskich. Jeżeli przyjmie się, że aktualność takich fotografii może powracać, jak przyjmuje Sarbiński (Utwór fotograficzny i jego twórca, s. 277), to z tego przepisu mogą skorzystać także muzea i archiwa. Jest to jednak dyskusyjne, ponieważ przepis ten jest wyjątkiem i jako takie nie powinien być przedmiotem wykładni rozszerzającej.

${ }^{33}$ Zob. K. Gienas, Dozwolony użytek utworów chronionych [art. 28, nb 7-10], w: Ustawa o prawie autorskim i prawach pokrewnych. Komentarz, red. E. Ferenc-Szydełko, Warszawa 2011, s. $154-223$.

${ }^{34}$ Tamże.

${ }^{35}$ Tamże. 
Powstaje wobec powyższego pytanie, czy osoby trzecie mogą domagać się od muzeów i archiwów kościelnych dostępu do nośników utworów fotograficznych, gdy prawa do utworu już wygasły? Przyjąć trzeba, że wprawdzie osoba trzecia ma swobodę korzystania z utworu, ale nie oznacza to, że może domagać się od innej osoby, która dysponuje nośnikiem takiego utworu, często jedynym, udostępnienia jej tego nośnika celem korzystania z utworu. Swoboda korzystania z utworu w stosunku, do którego wygasły autorskie prawa majątkowe, nie oznacza nabycia swoistego prawa domagania się udostępnienia nośnika utworu celem korzystania z utworu. Przeciwnie, to właściciel nośnika utworu jest wyłącznie uprawniony i może domagać się, aby osoby trzecie, nie wkraczały w jego prawo wyłącznego korzystania z nośnika utworu (art. 140 k.c.).

Po wygaśnięciu autorskich praw majątkowych do utworu archiwa i muzea mogą swobodnie korzystać z utworów, w szczególności dokonywać ich utrwalenia, zwielokrotnienia i rozpowszechniania, np. przez digitalizację zbiorów. Wprawdzie utwory fotograficzne podlegające digitalizacji, nie mają już z majątkowej ochrony prawno-autorskiej, ale powstaje pewna treść cyfrowa ${ }^{36}$, której właścicielem jest podmiot dokonujący tej digitalizacji. Wydaje się, że można go traktować jako uprawnionego do dysponowania takimi zasobami cyfrowymi, w szczególności nie ma on obowiązku udostępniania ich innym osobom. Jeżeli jednak zgodzi się na taki dostęp, to wydaje się, że nie może go potem ograniczać, ponieważ postanowienia umowne określające zasady, cele, czas itp. korzystania z takich treści cyfrowych, nie będą skuteczne. Stoją one bowiem w sprzeczności z zasadą swobodnego dostępu do utworu przez wszystkich po wygaśnięciu jego autorskich praw majątkowych.

\section{REFERENCES / BIBLIOGRAFIA}

\section{Akty prawne}

Ustawa z dnia 29 marca 1926 r. o prawie autorskim (Dz. U. z 1926 r. Nr 48, poz. 286).

Ustawa z dnia 23 kwietnia 1964 r. - Kodeks cywilny (tekst jedn.: Dz. U. z 2020 r. poz. 1740).

Ustawa z dnia 14 lipca 1983 r. o narodowym zasobie archiwalnym i archiwach (tekst jedn.: Dz. U. z 2020 r. poz. 164 z późn. zm.).

Ustawa z dnia 4 lutego 1994 r. o prawie autorskim i prawach pokrewnych (tekst jedn.: Dz. U. z 2021 r. poz. 1062).

Ustawa z dnia 21 listopada 1996 r. o muzeach (tekst jedn.: Dz. U. z 2020 r. poz. 902).

${ }^{36}$ Zob. M. Jagielska, Treści cyfrowe jako przedmiot stosunków cywilnoprawnych, w: Aksjologia prawa cywilnego i cywilnoprawna ochrona dóbr, red. J. Pisuliński, J. Zawadzka, Warszawa 2020, s. 283. 
Gesetz vom 09.09.1965 über Urheberrecht und verwandte Schutzrechte, BGB1. I S. 1273, zuletzt geändert durch Gesetz vom 31.05.2021, BGBl. I S. 1204 [Ustawa z dnia 9 września 1965 r. o prawie autorskim i pokrewnych prawach chronionych, Federalny Dziennik Ustaw I, s. 1273 ze zm., ostatnia zm. przez ustawę z dnia 31 maja 2021 r., Federalny Dziennik Ustaw I, s. 1204].

\section{Orzecznictwo}

Orzeczenie Sądu Najwyższego z dnia 12 marca 1958 r., II CR 374/57, „Orzecznictwo Sądów Polskich", 1959, z. 5, poz. 125.

Uzasadnieniu wyroku Sądu Najwyższego z dnia 10 maja 1976 r., IV CR 127/76, „Orzecznictwo Sądu Najwyższego. Izba Cywilna”, (1977) nr 4, poz. 69.

Uzasadnienie wyroku Sądu Najwyższego z dnia 8 sierpnia 1978 r., II CR 242/78, LEX nr 63857.

Wyrok Sądu Najwyższego z dnia 5 lipca 2002 r., III CKN 1096/00, „Orzecznictwo Sądu Najwyższego. Izba Cywilna”, (2003) nr 11, poz. 150.

Wyrok Sądu Apelacyjnego w Poznaniu z dnia 30 czerwca 1992 r., I ACr 220/92, „Orzecznictwo Sądów Apelacyjnych”, (1993) nr 4, poz. 24.

\section{Opracowania}

Barta Janusz, Markiewicz Ryszard, Przedmiot prawa autorskiego, w: System prawa prywatnego. Prawo autorskie, t. 13, red. J. Barta, Warszawa 2007, s. 7-61. Barta Janusz, Markiewicz Ryszard, Glosa do wyroku SA w Gdańsku z dnia 29 stycznia 1993 r. AGCr 369/92, „Orzecznictwo Sądów Polskich”, (1993) nr 11, poz. 216.

Błeszczyński Jan, Prawo autorskie, wyd. 3, Warszawa 1988.

Błeszczyński Jan, Twórczość jako przesłanka ochrony w polskim prawie autorskim $w$ świetle doktryny i orzecznictwa, w: Wspótczesne problemy prawa prywatnego. Ksiegga pamiatkowa ku czci profesora Edwarda Gniewka, red. J. Gołaczyński, P. Machnikowski, Warszawa 2010, s. 27-40.

Ferenc-Szydełko Ewa, Przedmiot prawa autorskiego, w: Ustawa o prawie autorskim i prawach pokrewnych. Komentarz, red. E. Ferenc-Szydełko, Warszawa 2011, s. 5-78.

Gienas Krzysztof, Dozwolony użytek utworów chronionych [art. 28, nb 7-10], w: Ustawa o prawie autorskim i prawach pokrewnych. Komentarz, red. E. Ferenc-Szydełko, Warszawa 2011, s. 154-223.

Golat Rafał, Prawo autorskie i prawa pokrewne, Warszawa 1999.

Grzeszak Teresa, Droit de suite w prawie autorskim, Warszawa 1991.

Grzybczyk Katarzyna, Przedmiot prawa autorskiego [art. 1, nb 96], w: Ustawa o prawie autorskim i prawach pokrewnych. Komentarz, red. P. Slęzak, Warszawa 2017, s. 5-40.

Jagielska Monika, Treści cyfrowe jako przedmiot stosunków cywilnoprawnych, w: Aksjologia prawa cywilnego i cywilnoprawna ochrona dóbr, red. J. Pisuliński, J. Zawadzka, Warszawa 2020, s. 283-302. 
Karpowicz Andrzej, Konstrukcje prawne w dziedzinie ochrony twórczości fotograficznej, „Refleks”, (1971) nr 17-18, s. 72-79.

Kopff Andrzej, Dzieło i jego twórca, w: Zagadnienia prawa autorskiego, S. Grzybowski, A. Kopff, J. Serda, Warszawa 1973, s. 11-33.

Kummer Max, Das urheberrechtlich schützbare Werk, Bern, 1968.

Loewenheim Urlich, Das Werk, w: Urheberrecht. Kommentar, Hrsg. G. Schricker, München, 1999, s. 97-157.

Łukaszczyk Joanna, Fotografia jako przedmiot prawa autorskiego - zarys problematyki elementów twórczych w fotografii, „Naukowy Przegląd Dziennikarski”, (2016) nr 3, s. 19-26.

Michalski Bogdan, Problemy prawne fotografii artystycznej, „Refleks”, (1970) nr 14 , s. 8-12.

Pers Łukasz, Utwory fotograficzne w regulacjach prawa autorskiego od czasów II Rzeczypospolitej do chwili obecnej. Analiza prawnoporównawcza, „Studenckie Zeszyty Naukowe", 22 (2019) nr 41, s. 129-139.

Poźniak-Niedzielska Maria, Przedmiot prawa autorskiego, w: System prawa prywatnego. Prawo autorskie, t. 13, red. J. Barta, Warszawa 2007, s. 8-17.

Rehbinder Manfred, Urheberrecht, München 2008.

Ritterman Stefan, Komentarz do ustawy o prawie autorskim, Kraków 1937.

Sarbiński Rafał Marcin, Utwór fotograficzny i jego twórca w prawie autorskim, Kraków 2004.

Schack Haimko, Urheber- und Urhebervertragsrecht, Tübingen 2005.

Stelmach Adam, Kopciuszek prawa autorskiego, „Prawo i Życie”, (1967) nr 8, s. 4. 


\title{
A PHOTOGRAPHIC WORK AND ITS MEDIUM IN THE ACTIVITY OF CHURCH ARCHIVES AND MUSEUMS
}

\begin{abstract}
Church museums and archives hold diverse categories of photographs. This diversity, combined with the fact that a photograph reflects an image of reality by technical means, raises the question of whether and which photographs are creative works subject to copyright protection. Eventually, the prevailing view was that a photograph reflects the image of reality, which is, however, modified by the photographer, thus potentially qualifying it as a creative work. In Polish literature and judicature the perception of requirements for a photograph to be considered a creative work changed over the years. Initially, only photographs characterized by artistry (beauty) achieved by the photographer's efforts, such as aesthetic positioning of people, use of light etc., were regarded as creative works (this view seems to be still present in German literature). Later on, the requirements photographs had to meet to be seen as creative works gradually became more liberal.

The key meaning was given to the subjective image of reality recorded by the author, which each time differs from the other image even of the same reality. If the subjective image based on the photographer's choice of the captured fragment of reality is decisive for meeting the requirements for creative works, i.e. creative activity and individual character, every photograph is a creative work with the exception of those that are devoid of the element of choice, e.g. ID photos. However, it could be argued that the prevailing prerequisites are not stringent enough. Museums and archives hold photographic prints which cannot be equated with a photographic work. The medium of a photographic work and a photographic work are different legal and conceptual categories: the former is a physical object to which one has the right of ownership and the latter is in copyright. The ownership of the medium does not grant the right to the author's economic rights.
\end{abstract}

Keywords: photographic work; copyright; church archives; museums; collections 